\title{
Finding the Optimal Conditioning Regimen for Relapsed/ Refractory Lymphoma Patients Undergoing Autologous Hematopoietic Cell Transplantation: A Retrospective Comparison of BEAM and High-Dose ICE
}

\author{
Otolog Hematopoetik Kök Hücre Nakli Yapılan Nüks/Dirençli Lenfoma Hastalarında BEAM ve \\ Yüksek Doz ICE Rejimlerinin Geriye Dönük Karşılaştııılması
}

Onur Esbah11, Emre Tekgündüz², Itır Şirinoğlu Demiriz², Sinem Civriz Bozdağ22, Ali Kaya², Ayşegül Tetik², Ömür Kayıkçı², Gamze Durgun², Şerife Kocubaba2, Fevzi Altuntaş2

${ }^{1}$ Ankara Oncology Hospital, Clinic of Medical Oncology, Ankara, Turkey

${ }^{2}$ Ankara Oncology Hospital, Hematology and Stem Cell Transplantation Unit, Ankara, Turkey

Abstract

Objective: High-dose chemotherapy followed by autologous hematopoietic stem cell transplantation (AHCT) is a well-defined treatment modality for relapsed/refractory non-Hodgkin's lymphoma $(\mathrm{NHL})$ and Hodgkin's lymphoma (HL). Although there are several options in terms of conditioning regimens before AHCT, no one treatment is accepted as a standard of care. This study aimed to compare different conditioning regimens for the treatment of $\mathrm{NHL}$ and $\mathrm{HL}$.

Materials and Methods: Medical records of 62 patients who had undergone AHCT following BEAM (BCNU, etoposide, cytarabine, and melphalan) and high-dose ICE (hICE; ifosfamide, carboplatin, and etoposide) conditioning regimens were analyzed retrospectively and compared in terms of efficacy and adverse effects.

Results: The study included a total of 29 and 33 patients diagnosed with relapsed/refractory $\mathrm{NHL}$ and $\mathrm{HL}$, respectively. Patients received BEAM $(n=37)$ or hICE $(n=25)$ regimens for conditioning. One-year overall survival was $73 \pm 6 \%$ in all patients. One-year overall survival was $71 \pm 8 \%$ and $74 \pm 9 \%$ in the BEAM and hICE groups, respectively $(p=0.86)$. The incidences of nausea/vomiting (grade $\geq 2)(84 \%$ vs. $44.7 \% ; p=0.04)$ and mucositis (grade $\geq 2)(13 \%$ vs. $3 \% ; p=0.002)$ were higher in the hICE group compared to the BEAM group. In addition, we witnessed significantly more hepatotoxicity of grade $\geq 2(40 \%$ vs. $2.7 \% ; p<0.005)$ and nephrotoxicity of grade $\geq 2(48 \%$ vs. $2.7 \%$; $\mathrm{p}<0.005)$ among patients who received hICE. Significantly more patients $(n=4 ; 25 \%)$ in the hICE group experienced veno-occlusive disease (VOD) compared to the BEAM arm, where no patients developed VOD $(p=0.01)$.

Conclusion: There was no difference in terms of overall survival between the BEAM and hICE groups. We observed significantly more adverse effects among patients treated with hICE. The BEAM regimen seems to be superior to hICE in terms of toxicity profile with comparable efficacy in patients with relapsed/refractory NHL and HL.

Keywords: Relapsed/refractory lymphoma, Hematopoietic stem cell transplantation, Conditioning regimen
$\ddot{O z}$

Amaç: Otolog kök hücre nakli (OKHN) destekli yüksek doz kemoterapi relaps/refrakter non-Hodgkin lenfoma (NHL) ve Hodgkin lenfoma (HL) tedavisinde uygulanan bir yöntemdir. Hazırlama rejimleri çok çeşitli olabilse de OKHN öncesinde henüz hiçbirisi standart olarak kabul edilmemiştir.

Gereç ve Yöntemler: BEAM ve yüksek doz ICE (hICE) sonrasında OKHN olan 62 hastanın tıbbi kayıtları retrospektif olarak analiz edildi ve etkinlik ile yan etki profili açısından karşılaştırıldı.

Bulgular: Çalışmaya toplamda 29 relaps/refrakter NHL ve $33 \mathrm{HL}$ olgusu dahil edildi. Hazırlama rejimleri BEAM $(n=37)$ ve hICE $(n=25)$ idi. Bir yıllık genel sağkalım (GS) \%73 $\% \% 6$ idi. BEAM ve hICE gruplarında ise 1 yıllık GS oranı sırasıyla $\% 71 \pm \% 8$ ve $\% 74 \pm \% 9$ olarak bulundu $(p=0,86)$. Bulantı/kusma (derece $\geq 2)$ insidansı $(\% 84$ vs $\% 44,7 ; p=0,04)$ ve mukozit (derece $\geq 2$ ) insidansı ( $\% 13$ vs $\% 3 ; p=0,002)$ hICE grubunda daha yüksek oranda görüldü. İlaveten, hICE alan hastalarda istatistiksel olarak derece $\geq 2$ hepatotoksisite ( $\% 40$ vs $\% 2,7 ; p<0,005$ ) ve derece $\geq 2$ nefrotoksisite $(\% 48$ vs $\% 2,7 ; p<0,005)$ daha fazla oranda gözlendi. hICE grubunda veno-oklüzif hastalık $(\mathrm{VOH})$ sıklığı $(n=4 ; 25 \%)$ BEAM grubu ile karşılaştırıldığında istatistiksel olarak anlamlı düzeyde daha yüksekti $(p=0,01)$. BEAM grubunda $\mathrm{VOH}$ görülmedi.

Sonuç: GS oranları her iki grup arasında farklı bulunmadı ancak hICE grubunda anlamlı oranda yan etki sıklığı artmıştır. Relaps/refrakter $\mathrm{NHL}$ ve HL hastalarında benzer etkinlik ile BEAM rejimi toksisite profili açısından hICE rejiminden üstün olarak kabul edilebilir.

Anahtar Sözcükler: Nüks/dirençli lenfoma, Hematopoetik kök hücre nakli, Hazırlama rejimi
Address for Correspondence/Yazışma Adresi: Itır ŞíRINOĞLU DEMIRiZ, M.D., Ankara Oncology Hospital, Hematology and Stem Cell Transplantation Unit, Ankara, Turkey Phone : +900532 2968998

E-mail : dritir@hotmail.com
Received/Geliş tarihi: May 28, 2014 Accepted/Kabul tarihi: January 19, 2015 


\section{Introduction}

About 50\% and $20 \%$ of patients presenting with non-Hodgkin's lymphoma (NHL) and Hodgkin's lymphoma ( $\mathrm{HL})$ will not be cured after initial combination chemotherapy, respectively $[1,2]$. High-dose chemotherapy combined with autologous hematopoietic stem cell transplantation (AHCT) is an accepted treatment option for relapsed/refractory chemosensitive $\mathrm{NHL} /$ HL patients $[3,4]$. Predictive markers for post-AHCT outcome are chemosensitivity, number of chemotherapy lines before AHCT, disease status at the time of AHCT, relevant prognostic scores for histological subtypes of lymphoma, and time of relapse following first-line therapy $(<12$ months vs. $>12$ months) $[5,6,7,8]$. The best conditioning regimen before AHCT in patients with relapsed/refractory lymphoma is an undefined issue. Commonly used regimens in this scenario are BEAM (BCNU, etoposide, cytarabine, and melphalan) [8,9], BEAC (BCNU, etoposide, cytarabine, cyclophosphamide) [9], highdose ICE (hICE; ifosfamide, carboplatin, and etoposide) [10], CMV (cyclophosphamide, melphalan, and etoposide) [11], CBV (cyclophosphamide, BCNU, and etoposide), combination regimens including total body irradiation (TBI) [12], and rituximab or I131-tositumomab combined with BEAM [13]. Few studies were reported comparing conditioning regimens in terms of toxicity and efficacy $[9,13,14,15,16]$. As we are unaware of any study comparing hICE and BEAM, we retrospectively analyzed our lymphoma patients who had undergone AHCT and received either hICE or BEAM regimens as conditioning.

\section{Materials and Methods}

\section{Patient Characteristics}

The clinical and laboratory records of all consecutive relapsed/ refractory $\mathrm{HL} / \mathrm{NHL}$ patients who were treated with AHCT between 2010 and 2012 were retrospectively analyzed. We did not use any exclusion criteria. All patients gave informed consent for all aspects of AHCT and the institutional review board approved the study.

\section{Mobilization Strategy}

We used a step-by-step mobilization strategy. Granulocytecolony stimulating factor (G-CSF; filgrastim or lenograstim) at a dose of $10 \mu \mathrm{g} / \mathrm{kg} /$ day in two divided doses is our first-line mobilization protocol. A progenitor cell yield of $<2 \times 10^{6} / \mathrm{kg}$ $\mathrm{CD}_{4}{ }^{+}$cells was defined as mobilization failure. G-CSF alone was used in patients who received not more than two lines of chemotherapy and did not need chemotherapy for tumor control. Patients who failed mobilization with G-CSF alone, were heavily pretreated, or needed chemotherapy for debulking received G-CSF (10 $\mu \mathrm{g} / \mathrm{kg} /$ day; filgrastim or lenograstim) plus chemotherapy for mobilization (second-line mobilization). Patients who failed two lines of mobilization received G-CSF combined with plerixafor as third-line mobilization. The details of mobilization with G-CSF plus plerixafor can be found elsewhere [17]. Patients who still failed mobilization with the aforementioned protocols received autologous bone marrow transplant.

Patients who needed second-line mobilization protocols received various chemotherapy regimens like ASHAP (doxorubicin, methylprednisolone, high-dose cytarabine, and cisplatin), R-ASHAP (rituximab-ASHAP), R-ICE (rituximab, ifosfamide, carboplatin, and etoposide), VIGEPP (vinorelbine, gemcitabine, procarbazine, and prednisone), DHAP (dexamethasone, cytarabine, and cisplatin), and cyclophosphamide $\left(4 \mathrm{~g} / \mathrm{m}^{2}\right)$ $[18,19,20,21,22]$.

\section{High-Dose Chemotherapy Regimens and Treatment Protocol}

BEAM was our preferred conditioning regimen before AHCT. Currently, BCNU and intravenous melphalan are unavailable on the Turkish market. Both drugs are exported from the European Union under the supervision of the Drug and Pharmacy Agency of Turkey. We used hICE as the second choice when one or both of these aforementioned drugs were temporarily unavailable for technical reasons. The BEAM regimen included BCNU at $300 \mathrm{mg} /$ $\mathrm{m}^{2}$ on day -7 , etoposide at $200 \mathrm{mg} / \mathrm{m}^{2}$ and cytarabine at 200 $\mathrm{mg} / \mathrm{m}^{2}$ on days -6 to -3 , and melphalan at $140 \mathrm{mg} / \mathrm{m}^{2}$ on day -2 . Patients in the hICE regimen group received ifosfamide at $2.5 \mathrm{~g} /$ $\mathrm{m}^{2}$ (total dose: $15 \mathrm{~g} / \mathrm{m}^{2}$; IV infusion over $2 \mathrm{~h}$ ), etoposide at 250 $\mathrm{mg} / \mathrm{m}^{2}$ (total dose: $1.5 \mathrm{~g} / \mathrm{m}^{2}$; IV infusion over $2 \mathrm{~h}$ ), carboplatin at $250 \mathrm{mg} / \mathrm{m}^{2}$ (total dose: $1.5 \mathrm{~g} / \mathrm{m}^{2}$; IV infusion over $4 \mathrm{~h}$ ), and mesna at $3.5 \mathrm{~g} / \mathrm{m}^{2}$ (total dose: $21 \mathrm{~g} / \mathrm{m}^{2}$ ) in evenly divided daily doses on days -8 to -3 .

Patients received subcutaneous G-CSF ( $5 \mu \mathrm{g} / \mathrm{kg} /$ day) from day +1 of AHCT until neutrophil engraftment $\left(>500 / \mathrm{mm}^{3}\right)$. Platelet transfusions were given if platelet counts were $<10,000 / \mathrm{mm}^{3}$ without risk factors for bleeding. Erythrocyte suspensions were given to patients with anemia-related symptoms or hemoglobin values below $8 \mathrm{~g} / \mathrm{dL}$. All patients received levofloxacin at 400 $\mathrm{mg} /$ day, fluconazole at $200 \mathrm{mg} /$ day, and valacyclovir at 1000 $\mathrm{mg} /$ day until neutrophil engraftment.

\section{Response and Toxicity Evaluation}

Responses before and after AHCT were evaluated according to revised international working group criteria [23]. Chemosensitive disease was defined as achievement of at least partial remission (PR) following salvage chemotherapy. Chemoresistant disease was defined as inability to achieve PR or observation of progressive disease. Positron emission tomography scanning was not used. Toxicities were evaluated according to Common Terminology Criteria for Adverse Events v3.0 [24]. Followup examinations were carried out at day +30 after AHCT. Thereafter, surveillance examinations were done every 3 months 
for the first 2 years, every 6 months for the next 3 years, and then annually.

\section{Definition of Engraftment, Febrile Neutropenia, and Veno- Occlusive Disease}

Neutrophil engraftment was defined as the first of 3 consecutive days on which the absolute neutrophil count exceeded 500/ $\mathrm{mm}^{3}$ without G-CSF support. Platelet engraftment was defined as the first day of 7 consecutive days on which platelet count exceeded $20,000 / \mathrm{mm}^{3}$ without platelet transfusion [25]. We used Infectious Disease Society of America [26] and Seattle [27] criteria for defining febrile neutropenia and veno-occlusive disease, respectively.

\section{Management of Febrile Neutropenia}

The details of our protocol can be found elsewhere [28]. Briefly, patients with febrile neutropenia who were not responding to broad-spectrum antibiotics for $72 \mathrm{~h}$ were evaluated for opportunistic fungal infections. Patients who had hemodynamic instability and/or two consecutive positive serum galactomannan assays (ELISA: optical density of $\geq 0.5$ ) and/or thorax computerized tomography findings suggesting invasive pulmonary aspergillosis (nodules with/without halo sign, air crescent sign, and cavitation) supported by mycological cultures received antifungal treatment. Patients with mycological evidence of Aspergillus spp. were treated with voriconazole. All others received caspofungin.

\section{Calculation of Direct Treatment Costs of Conditioning Regimens}

Direct drug costs of BEAM and hICE conditioning regimens were calculated based on an average patient with a body surface area of $1.7 \mathrm{~m}^{2}$ as of October 2013.

\section{Statistical Analysis}

Descriptive statistics are presented as median and minimummaximum. Comparisons of continuous variables between the two groups were performed using the nonparametric MannWhitney $\mathrm{U}$ test. Proportions were compared using the chisquare test. Survival analysis was calculated with Kaplan-Meier analysis. A p-value below 0.05 was considered to be statistically significant.

\section{Results}

The demographic and clinical characteristics of the study cohort are summarized in Table 1. Fifteen (40\%) and $5(20 \%)$ patients had primary refractory disease following their firstline chemotherapy in the BEAM and hICE groups, respectively $(p=0.09)$. While 6 patients in the BEAM group received standard-dose ICE (sICE) as rescue before AHCT, no patient in the hICE arm was treated with sICE as salvage chemotherapy.
Fourteen (38\%) and $6(25 \%)$ patients of the BEAM and hICE arms had refractory disease at AHCT, respectively. Twenty-six, 28, 8 patients were mobilized with G-CSF alone, G-CSF plus chemotherapy, G-CSF plus plerixafor, respectively. There were no significant differences in terms of conditioning regimens among patient groups ( $\mathrm{p}=0.5$ both for $\mathrm{HL}$ and NHL patients). The treatment arms were also similar according to age, sex, stage, previous radiotherapy, chemotherapy history, and disease status at AHCT and mobilization protocol. On the other hand, the BEAM group had significantly worse performance status compared to the hICE arm $(p=0.011)$ (Table 1$)$.

Mobilization success, engraftment kinetics, and side effect profiles of the conditioning regimens are given in Table 2. The BEAM and hICE treatment arms were similar in terms of infused stem cells, median days with febrile neutropenia, engraftment kinetics, and duration of hospitalization. We observed significantly more adverse effects (grade $\geq 2$ ) in terms of nausea/ vomiting, mucositis, hepatotoxicity, and nephrotoxicity among patients treated with hICE conditioning compared to patients who received BEAM. Significantly more patients $(n=4 ; 25 \%)$ in the hICE group experienced veno-occlusive disease compared to the BEAM arm, where no patients developed veno-occlusive disease $(p=0.01)$. The treatment arms were comparable according to diarrhea rate $(p=0.09)$.

Relapse rates following BEAM and hICE conditioning regimens were $13.5 \%(5 / 37)$ and $32 \%(8 / 25)(p=0.07)$. One patient of the BEAM arm died before day 30 following AHCT as a result of sepsis. Additionally, two patients (one patient in each arm) died before day 100. The reasons for mortality were sepsis/ engraftment failure and Cytomegalovirus pneumonia in the patients of the BEAM and hICE groups, respectively. Transplantrelated mortality for the entire cohort on day 100 was $4.8 \%$ (BEAM: 5.4\%; hICE: 4\%; $p=0.8$ ). Following AHCT, 5 (13.5\%) and $8(32 \%)$ patients of the BEAM and hICE arms relapsed ( $p=0.07)$. Three-year disease-free survival (DFS) and overall survival (OS) rates were $52 \pm 10 \%$ and $57 \pm 6 \%$ in the whole study cohort, respectively. There was no difference in terms of 3-year DFS rates according to conditioning regimens (BEAM: $63 \pm 13 \%$; hICE: $42 \pm 15 \% ; p=0.187$ ) (Figure 1). Three-year OS was $56.8 \pm 8 \%$ and $58 \pm 10 \%$ in the BEAM and hICE groups, respectively $(p=0.781)$ (Table 2, Figure 2).

Direct treatment costs of hICE and BEAM regimens were found to be 1721 and 582 euro, respectively.

\section{Discussion}

Although many different conditioning regimens for relapsed/ refractory $\mathrm{HL}$ and $\mathrm{NHL}$ have been proposed, none of them can be considered as a standard of care $[8,9,10,11,12]$. Different types of hICE conditioning regimens were described according 
to large ranges of cumulative dosages and administrations of drugs $[10,29]$. To our knowledge, there is no direct comparison in the literature of BEAM and hICE chemotherapy regimens in patients who have undergone AHCT for relapsed/refractory lymphoma.

In the current study, we observed statistically significant differences in terms of toxicity favoring the BEAM regimen compared to hICE. It was not surprising that nausea and vomiting were more frequent in the hICE arm, as ifosfamide and carboplatin have high emetogenic potential. Mucositis is an important toxicity of BCNU and etoposide $[30,31]$. According to several studies, BCNU-related mucositis rates were higher when the BCNU dose was increased from 450 to $600 \mathrm{mg} / \mathrm{m}^{2}$ [30]. The BCNU dose in the BEAM conditioning arm was $300 \mathrm{mg} / \mathrm{m}^{2}$ in our study. The total doses of etoposide were $1500 \mathrm{mg} / \mathrm{m}^{2}$ and $800 \mathrm{mg} / \mathrm{m}^{2}$ in the hICE and BEAM arms, respectively. The higher etoposide dose may be responsible for the higher mucositis rate observed in the hICE arm. Nephrotoxicity was significantly higher in the hICE group $(p<0.005)$. Nephrotoxicity was seen only in one patient in the BEAM group. This is not an unexpected finding because carboplatin and ifosfamide are well-known nephrotoxic agents [32]. Hepatotoxicity was also more frequent in the hICE group than the BEAM group $(p<0.005)$. Patients on hICE experienced significantly more veno-occlusive disease compared to the BEAM arm. This may have occurred as a result of the higher total dose of etoposide in hICE compared to BEAM [31]. In addition, ifosfamide may create an extra burden on the liver, resulting in high rates of hepatotoxicity [33]. As no patient in the hICE arm received sICE as a salvage before AHCT, we think that the observed toxicity cannot be attributed to previous exposure to the same drugs at standard doses.

In Turkey, direct treatment costs of ICE and BEAM regimens in a patient with an average body surface area of $1.7 \mathrm{~m}^{2}$ are 1721 and 582 euro, respectively. Indirect costs of chemotherapy like hospitalization, treatment of infections, or adverse effects are not included here. The BEAM regimen was more advantageous in terms of cost.

Table 1. Demographic and clinical characteristics of patient cohorts.

\begin{tabular}{|c|c|c|c|}
\hline & BEAM $(n=37)$ & hICE $(n=25)$ & $\mathbf{p}$ \\
\hline $\mathrm{HL}$ & 18 & 15 & 0.5 \\
\hline NHL & 19 & 10 & \\
\hline DLBCL/FL/MCL & $7 / 6 / 1$ & $5 / 3 / 1$ & 0.5 \\
\hline PTCL/ALCL & $4 / 1$ & $1 /-$ & \\
\hline Male/female & $22 / 15$ & $17 / 8$ & 0.49 \\
\hline Median age, years (min-max) & $38(17-70)$ & $40(20-64)$ & 0.76 \\
\hline Stage (I/II/III/IV) & $4 / 11 / 17 / 5$ & $3 / 4 / 11 / 7$ & 0.35 \\
\hline ECOG (I/II/III/IV) & $4 / 23 / 10 /-$ & $11 / 9 / 5 /-$ & 0.011 \\
\hline Previous radiotherapy & $9(24 \%)$ & $4(16 \%)$ & 0.33 \\
\hline Previous lines of chemotherapy (1st/2nd/3rd/4th) & $2 / 19 / 14 / 2$ & $2 / 17 / 6 /-$ & 0.37 \\
\hline \multicolumn{4}{|l|}{ Response to first-line chemotherapy } \\
\hline Primary refractory disease & $15(40 \%)$ & $5(20 \%)$ & 0.09 \\
\hline Chemosensitive disease (at least PR) & $22(60 \%)$ & $20(80 \%)$ & \\
\hline \multirow[t]{8}{*}{ First-line salvage chemotherapy } & DHAP $(n=15)$ & DHAP $(n=9)$ & \\
\hline & ASHAP $(n=1)$ & ASHAP $(n=10)$ & \\
\hline & sICE $(n=6)$ & $\operatorname{CVP}(n=1)$ & \\
\hline & ABVD $(n=4)$ & $\mathrm{CHOP}(n=1)$ & \\
\hline & BEACOPP $(n=1)$ & $\mathrm{R}-\mathrm{FC}(\mathrm{n}=1)$ & \\
\hline & Hyper-CVAD $(n=1)$ & R-MINE $(n=1)$ & \\
\hline & & Hyper-CVAD $(n=1)$ & \\
\hline & & $\operatorname{VIGEPP}(n=1)$ & \\
\hline Disease status at AHCT (CR/PR/refractory) & $17 / 6 / 14$ & $16 / 3 / 6$ & 0.490 \\
\hline \multicolumn{4}{|l|}{ Mobilization } \\
\hline (G-CSF/G-CSF+chemotherapy/G-CSF+plerixafor & $15 / 19 / 3$ & $11 / 9 / 5$ & 0.37 \\
\hline \multicolumn{4}{|c|}{$\begin{array}{l}\text { HL: Hodgkin's lymphoma, NHL: non-Hodgkin's lymphoma, DLBCL: diffuse large B-cell lymphoma, FL: follicular lymphoma, MCL: mantle cell lymphoma, ECOG: The Eastern Cooperative } \\
\text { Oncology Group, PTCL: peripheral T cell lymphoma ALCL: anaplastic large cell lymphoma, G-CSF: granulocyte-colony stimulating factor, AHCT: autologous hematopoietic stem cell } \\
\text { transplantation, PR: partial remission, CR: complete remission, ASHAP: doxorubicin, methylprednisolone, high-dose cytarabine, and cisplatin, R-ASHAP: rituximab-ASHAP, R-ICE: } \\
\text { rituximab, ifosfamide, carboplatin, and etoposide, VIGEPP: vinorelbine, gemcitabine, procarbazine, and prednisone, DHAP: dexamethasone, cytarabine, and cisplatin, sICE: standard- } \\
\text { dose ICE. }\end{array}$} \\
\hline
\end{tabular}


Head-to-head comparisons of different conditioning regimens in relapsed/refractory lymphoma patients before AHCT are scarce. Jo et al. observed superior OS and event-free survival at 2 years in patients on BEAM compared to BEAC regimens $(62.4 \%$ vs. $32.1 \%$ and $62.4 \%$ vs. $28.6 \%$, respectively). However, diarrhea and mucositis were more frequent in patients of the BEAM arm [9]. In their single-center analysis, Jantunen et al. reported similar efficacy of BEAM and BEAC conditioning regimens in terms of

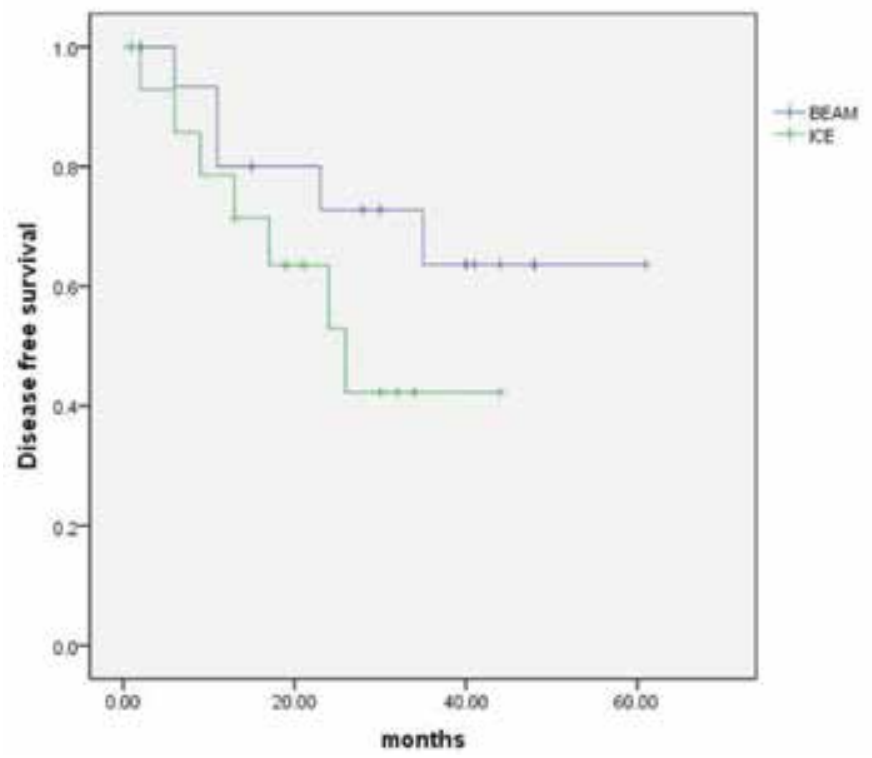

Figure 1. Kaplan-Meier plots of disease-free survival following autologous hematopoietic stem cell transplantation according to conditioning regimens. Three-year disease-free survival rates were $63 \pm 13 \%$ (BEAM) vs. $42 \pm 15 \%$ (hICE) $(p=0.187)$.
OS and progression-free survival in patients undergoing AHCT for $\mathrm{NHL}$, but BEAM was found more toxic to the gastrointestinal system [16]. In recent years the BEAM regimen was also compared with the CEB (carboplatin, etoposide, and bleomycin) regimen with better OS in favor of BEAM [14], but other studies reported conflicting results [15]. Salar et al. reported Spanish GEL/TAMO registry data including 395 consecutively autografted diffuse large B-cell lymphoma (DLBCL) patients.

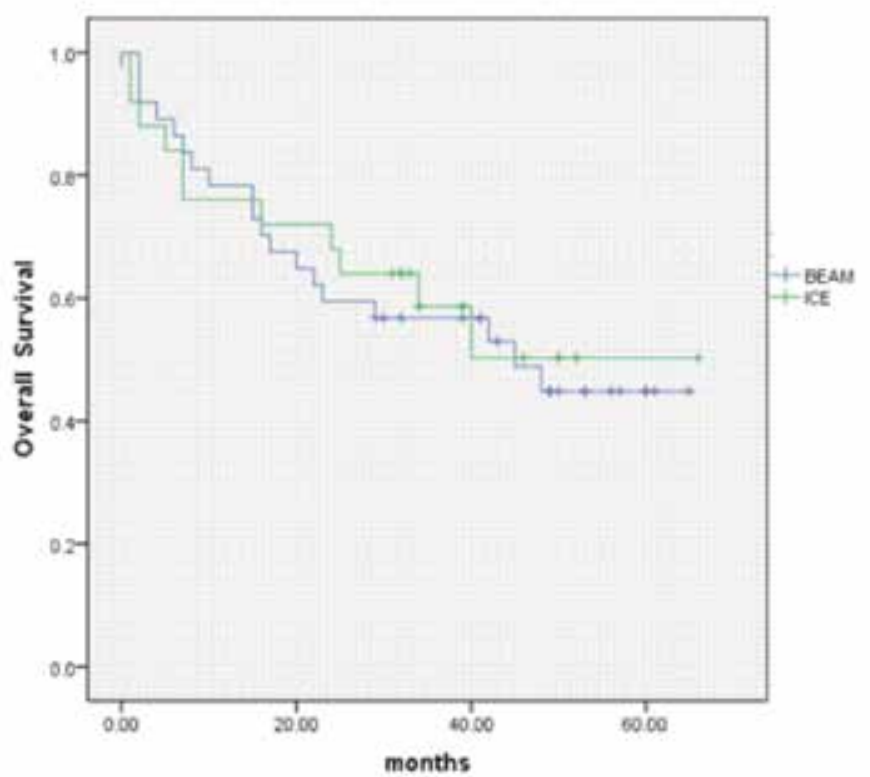

Figure 2. Kaplan-Meier plots of overall survival following autologous hematopoietic stem cell transplantation according to conditioning regimens. Three-year overall survival rates were $56 \pm 8 \%$ (BEAM) vs. $58 \pm 10 \%$ (hICE) $(p=0.781)$.

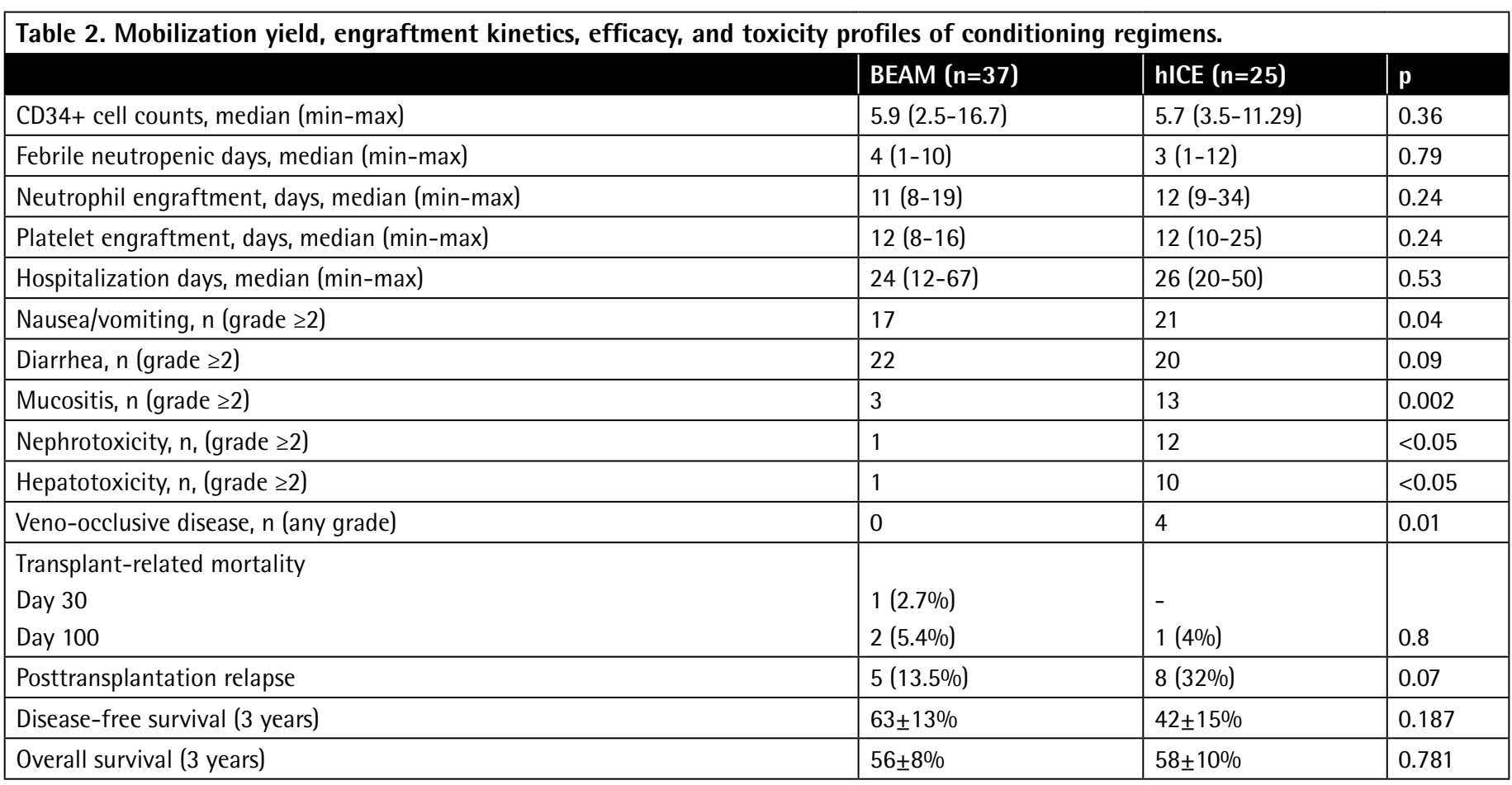


The main message of that study was that chemotherapy-only conditioning regimens (BEAM, BEAC, or CBV) significantly improved 8-year OS compared to TBI + cyclophosphamide [15]. Recently, the rituximab-BEAM (R-BEAM) conditioning regimen was compared to the 131-tositumomab-BEAM (B-BEAM) in a phase III randomized study in relapsed, chemosensitive DLBCL patients. Two-year progression-free survival and OS rates were comparable, but B-BEAM was found to be more toxic in terms of mucositis [13]. Although the observation period of our study cohort is limited, 3-year OS rates were similar in the BEAM and hICE arms ( $56 \pm 8 \%$ vs. $58 \pm 10 \% ; p=0.781)$. There was a trend for lower relapse rates following BEAM compared to hICE (13.5\% vs. $32 \% ; p=0.07)$. There were more patients with primary refractory disease ( $40 \%$ vs. $20 \%)$ and refractory disease at AHCT (38\% vs. $24 \%$ ) in the BEAM arm compared to patients receiving hICE conditioning. The aforementioned points underline the strong antitumor effect of the BEAM regimen compared to hICE. Taking the cost and safety advantages of BEAM over hICE in addition to similar short-term DFS and OS into account, it seems reasonable to suggest that BEAM seems to be a better option than hICE for conditioning in relapsed/refractory lymphoma patients undergoing AHCT.

Our study has several limitations that make it difficult to draw firm conclusions, such as the limited number of patients, retrospective design, and heterogeneous lymphoma subtypes of the cohort. As we included patients with $\mathrm{HL}$ and various pathologic subgroups of NHL (DLBCL, follicular lymphoma, mantle cell lymphoma, peripheral $\mathrm{T}$ cell lymphoma, and anaplastic large cell lymphoma), generalization of our findings may not be appropriate for specific patient populations with lymphoma. We also had a very limited number of patients with each subtype of lymphoma, making disease-specific statistical evaluation of hICE and BEAM conditioning regimens impossible. Although the BEAM treatment arm included more patients with poor performance status, the toxicity profile of BEAM was lower compared to ICE. This point again emphasizes that BEAM is a safe and effective conditioning regimen even for patients with poor performance.

In conclusion, the current retrospective study showed that BEAM seems to be a better option compared to hICE as a conditioning regimen in relapsed/refractory lymphoma patients before AHCT with similar efficacy but low toxicity. Although there was no difference in 3-year DFS and OS, the nausea/ vomiting, mucositis, nephrotoxicity, and hepatotoxicity rates were significantly higher in the hICE group compared to the BEAM group. Prospective studies with homogeneous patient populations and incorporating novel agents in the therapeutic armamentarium will be very informative in the search for the optimal conditioning regimen in specific lymphoma subtypes in the future.

\section{Ethics}

Ethics Committee Approval: Ethical Committee approval has been not taken because it is retrospective research; Informed Consent: It was taken.

\section{Authorship Contributions}

Medical Practices: Onur Esbah, Emre Tekgündüz, Itır Şirinoğlu Demiriz, Sinem Civriz Bozdağ, Ali Kaya, Ayşegül Tetik, Ömür Kayıkçı, Gamze Durgun, Şerife Kocubaba, Fevzi Altuntaş; Concept: Onur Esbah, Emre Tekgündüz, Itır Şirinoğlu Demiriz; Design: Onur Esbah, Emre Tekgündüz, Itır Şirinoğlu Demiriz; Data Collection or Processing: Onur Esbah, Emre Tekgündüz, Itır Şirinoğlu Demiriz, Sinem Civriz Bozdağ, Ali Kaya, Ayşegül Tetik, Ömür Kayıkçı, Gamze Durgun, Şerife Kocubaba, Fevzi Altuntaş; Analysis or Interpretation: Onur Esbah, Emre Tekgündüz, Itır Şirinoğlu Demiriz, Sinem Civriz Bozdağ; Literature Search: Onur Esbah, Emre Tekgündüz, Itır Şirinoğlu Demiriz, Sinem Civriz Bozdağ, Ali Kaya, Ayşegül Tetik, Ömür Kayıkçı, Gamze Durgun, Şerife Kocubaba, Fevzi Altuntaş; Writing: Onur Esbah, Emre Tekgündüz, Itır Şirinoğlu Demiriz, Sinem Civriz Bozdağ, Ali Kaya, Ayşegül Tetik, Ömür Kayıkçı, Gamze Durgun, Şerife Kocubaba, Fevzi Altuntaş.

Conflict of Interest: The authors of this paper have no conflicts of interest, including specific financial interests, relationships, and/or affiliations relevant to the subject matter or materials included.

\section{References}

1. Fisher RI, Gaynor ER, Dahlberg S, Oken MM, Grogan TM, Mize EM, Glick JH, Coltman CA Jr, Miller TP. Comparison of a standard regimen (CHOP) with three intensive chemotherapy regimens for advanced non-Hodgkin's lymphoma. N Engl J Med 1993;328:1002-1006.

2. Diehl V, Stein H, Hummel M, Zollinger R, Connors JM. Hodgkin's lymphoma: biology and treatment strategies for primary, refractory, and relapsed disease. Hematology Am Soc Hematol Educ Program 2003:225-247.

3. Philip T, Guglielmi C, Hagenbeek A, Somers R, Van der Lelie H, Bron D, Sonneveld P, Gisselbrecht C, Cahn JY, Harousseau JL, Coiffier B, Biron $\mathrm{P}$, Mandelli $\mathrm{F}$, Chauvin F. Autologous bone marrow transplantation as compared with salvage chemotherapy in relapses of chemotherapysensitive non-Hodgkin's lymphoma. N Engl J Med 1995;333:1540-1545.

4. Linch DC, Winfield D, Goldstone AH, Moir D, Hancock B, McMillan A, Chopra R, Milligan D, Hudson GV. Dose intensification with autologous bonemarrow transplantation in relapsed and resistant Hodgkin's disease: results of a BNLI randomised trial. Lancet 1993;341:1051-1054.

5. Crump M, Smith AM, Brandwein J, Couture F, Sherret H, Sutton DM, Scott JG, McCrae J, Murray C, Pantolony D, Sutcliffe SB, Keating A. High-dose etoposide and melphalan, and autologous bone marrow transplantation for patients with advanced Hodgkin's disease: importance of disease status at transplant. J Clin Oncol 1993;11:704-711.

6. O'Brien ME, Milan S, Cunningham D, Jones AL, Nicolson M, Selby $P$, Hickish T, Hill M, Gore ME, Viner C. High-dose chemotherapy and autologous bone marrow transplant in relapsed Hodgkin'sdisease--a pragmatic prognostic index. Br J Cancer 1996;73:1272-1277.

7. Gordon LI, Andersen J, Colgan J, Glick J, Resnick GD, O'Connell M, Cassileth PA. Advanced diffuse non-Hodgkin's lymphoma. Analysis of prognostic factors by the international index and by lactic dehydrogenase in an intergroup study. Cancer 1995;75:865-873. 
8. Abdel-Rahman F, Hussein A, Aljamily M, Al-Zaben A, Hussein N, Addasi A. High-dose therapy and autologous hematopoietic progenitor cells transplantation for recurrent or refractory Hodgkin's lymphoma: analysis of King Hussein Cancer Center results and prognostic variables. ISRN Oncol 2012;2012:249124.

9. Jo JC, Kang BW, Jang G, Sym SJ, Lee SS, Koo JE, Kim JW, Kim S, Huh J, Suh C. BEAC or BEAM high-dose chemotherapy followed by autologous stem cell transplantation in non-Hodgkin's lymphoma patients: comparative analysis of efficacy and toxicity. Ann Hematol 2008;87:43-48.

10. Fields KK, Elfenbein GJ, Lazarus HM, Cooper BW, Perkins JB, Creger RJ, Ballester OF, Hiemenz JH, Janssen WE, Zorsky PE. Maximum-tolerated doses of ifosfamide, carboplatin, and etoposide given over 6 days followed by autologous stem-cell rescue: toxicity profile. J Clin Oncol 1995;13:323-332.

11. Schütt $P$, Passon J, Ebeling $P$, Welt $A$, Müller $S$, Moritz $T$, Seeber $S$, Nowrousian MR. Ifosfamide, etoposide, cytarabine, and dexamethasone as salvage treatment followed by high-dose cyclophosphamide, melphalan, and etoposide with autologous peripheral blood stem cell transplantation for relapsed or refractory lymphomas. Eur J Haematol 2007;78:93-101.

12. Stiff PJ, Dahlberg S, Forman SJ, McCall AR, Horning SJ, Nademanee AP, Blume KG, LeBlanc M, Fisher RI. Autologous bone marrow transplantation for patients with relapsed or refractorydiffuse aggressive non-Hodgkin's Iymphoma: value of augmented preparative regimens--a Southwest Oncology Group trial. J Clin Oncol 1998;16:48-55.

13. Vose JM, Carter $\mathrm{S}$, Burns $\amalg$, Ayala E, Press OW, Moskowitz $\mathrm{CH}_{\text {, Stadtmauer }}$ EA, Mineshi S, Ambinger R, Fenske T, Horowitz M, Fisher R, Tombly M. Phase III randomized study of rituximab/carmustine, etoposide, cytarabine, and melphalan (BEAM) compared with iodine-131 tositumomab/BEAM with autologous hematopoietic cell transplantation for relapsed diffuse large B-cell lymphoma: results from the BMT CTN 0401 trial. J Clin Oncol 2013;31:1662-1668.

14. Wang EH, Chen $Y A$, Corringham $S$, Bashey $A$, Holman $P, B a l l ~ E D$, Carrier E. High-dose CEB vs BEAM with autologous stem cell transplantin lymphoma. Bone Marrow Transplant 2004;34:581-587.

15. Salar A, Sierra J, Gandarillas M, Caballero MD, Marín J, Lahuerta JJ, GarciaConde J, Arranz R, León A, Zuazu J, Garcia-Laraña J, López-Guillermo A, Sanz MA, Grañena A, García JC, Conde E; GEL/TAMO Spanish Cooperative Group. Autologous stem cell transplantation for clinically aggressive nonHodgkin's lymphoma: the role of preparative regimens. Bone Marrow Transplant 2001;27:405-412.

16. Jantunen E, Kuittinen T, Nousiainen T. BEAC or BEAM for high-dose therapy in patients with non-Hodgkin's lymphoma? A single centre analysis on toxicity and efficacy. Leuk Lymphoma 2003;44:1151-1158.

17. Tekgündüz $E$, Altuntaş $F$, Sıvgın $S, A k ı S Z$, Dönmez A, Topçuoğlu $P$, Yııdırım R, Baysal NA, Ayyıldız E, Yüksel MK, Sarı I, Tombuloğlu M, Unal A, Ilhan 0 . Plerixafor use in patients with previous mobilization failure: a multicenter experience. Transfus Apher Sci 2012;47:77-80.

18. Goldschmidt $H$, Hegenbart $U$, Haas R, Hunstein W. Mobilization of peripheral blood progenitor cells with high-dose cyclophosphamide $\left(4\right.$ or $\left.7 \mathrm{~g} / \mathrm{m}^{2}\right)$ and granulocyte colony-stimulating factor in patients with multiple myeloma. Bone Marrow Transplant 1996;17:691-697.

19. Gisselbrecht C, Glass B, Mounier N, Singh Gill D, Linch DC, Trneny M, Bosly A, Ketterer N, Shpilberg O, Hagberg H, Ma D, Brière J, Moskowitz CH, Schmitz $\mathrm{N}$. Salvage regimens with autologous transplantation for relapsed large B-cell lymphoma in the rituximab era. J Clin Oncol 2010;28:4184-4190.

20. Aydin S, Dührsen U, Nückel H. Rituximab plus ASHAP for the treatment of patients with relapsed or refractory aggressive non-Hodgkin's lymphoma: a single-centre study of 20 patients. Ann Hematol 2007;86:271-276.
21. Nückel H, Dürig J, Dührsen U. Salvage chemotherapy according to the ASHAP protocol: a single-center study of 24 patients with relapsed or refractory aggressive non-Hodgkin's lymphomas. Ann Hematol 2003;82:481-486.

22. Di Renzo N, Brugiatelli M, Montanini A, Vigliotti ML, Cervetti G, Liberati AM, Luminari S, Spedini P, Giglio G, Federico M. Vinorelbine, gemcitabine, procarbazine and prednisone (ViGePP) as salvage therapy in relapsed or refractory aggressive non-Hodgkin's lymphoma (NHL): results of a phase II study conducted by the Gruppo Italiano per lo Studio dei Linfomi. Leuk Lymphoma 2006;47:473-479.

23. Cheson BD, Pfistner B, Juweid ME, Gascoyne RD, Specht L, Horning SJ, Coiffier B, Fisher RI, Hagenbeek A, Zucca E,Rosen ST, Stroobants S, Lister TA, Hoppe RT, Dreyling M, Tobinai K, Vose JM, Connors JM, Federico M, Diehl $V_{i}$ International Harmonization Project on Lymphoma. Revised response criteria for malignant lymphoma. J Clin Oncol 2007;25:579-586.

24. Cancer Therapy Evaluation Program. Common Terminology Criteria for Adverse Events v3.0. Bethesda, MD, USA, CTEP, 2006.

25. Liu H, Rich ES, Godley L, Odenike O, Joseph L, Marino S, Kline J, Nguyen V, Cunningham J, Larson RA, del Cerro P, Schroeder L, Pape L, Stock W, Wickrema A, Artz AS, van Besien K. Reduced-intensity conditioning with combined haploidentical and cord blood transplantation results in rapid engraftment, low GVHD, and durable remissions. Blood 2011;118:64386445.

26. Freifeld AG, Bow EJ, Sepkowitz KA, Boeckh MJ, Ito Jl, Mullen CA, Raad II, Rolston KV, Young JA, Wingard JR; Infectious Diseases Society of America. Clinical practice guidelines for the use of antimicrobial agents in neutropenic patients with cancer: 2010 update by the Infectious Diseases Society of America. Clin Infect Dis 2011;52:56-93.

27. McDonald GB, Hinds MS, Fisher LD, Schoch $H G$, Wolford JL, Banaji M, Hardin BJ, Shulman HM, Clift RA. Veno-occlusive disease of the liver and multiorgan failure after bone marrow transplantation: a cohort study of 355 patients. Ann Intern Med 1993;118:255-267.

28. Ciledağ N, Arda K, Arıbaş BK, Tekgündüz Al, Altuntaş F. The role of multidetector computed tomography in early diagnosis of invasive pulmonary aspergillosis in patients with febrile neutropenia undergoing hematopoietic stem cell transplantation. Turk J Hematol 2012;29:28-33.

29. Wilson WH, Jain V, Bryant G, Cowan KH, Carter C, Cottler-Fox M, Goldspiel $B$, Steinberg SM, Longo DL, Wittes RE. Phase I and II of high-dose ifosfamide, carboplatin and etoposide with autologous bone marrow rescue in lymphomas and solid tumors. J Clin Oncol 1992;10:1712-1722.

30. Fleming DR, Wolff SN, Fay JW, Brown RA, Lynch JP, Bolwell BJ, Stevens DA, Goodman SA, Greer JP, Stein RS, Pineiro LA, Collins RH, Goldsmith $\mathrm{U}$, Herzig GP, Herzig RH. Protracted results of dose-intensive therapy using cyclophosphamide, carmustine, and continuous infusion etoposide with autologous stem cell support in patients with relapse or refractory Hodgkin's disease: a phase II study from the North American Marrow Transplant Group. Leuk Lymphoma 1999;35:91-98.

31. Ritchie DS, Szer J, Roberts AW, Shuttleworth P, Grigg AP. A phase I doseescalation study of etoposide continuous infusion added to busulphan/ cyclophosphamide as conditioning prior to autologous or allogeneic stem cell transplantation. Bone Marrow Transplant 2002;30:645-650.

32. Kim YI, Yoon JY, Hwang JE, Shim HJ, Bae WK, Cho SH, Chung IJ. Reversible proximal renal tubular dysfunction after one-time Ifosfamide exposure. Cancer Res Treat 2010;42:244-246.

33. Cheung MC, Jones RL, Judson I. Acute liver toxicity with ifosfamide in the treatment of sarcoma: a case report. J Med Case Rep 2011;5:180. 